\title{
DIGLOSIA
}

Terakreditasi Sinta 3 | Volume 3 | Nomor 3 | Tahun 2020 | Halaman 253-262

P-ISSN 2615-725X | E-ISSN 2615-8655

http://diglosiaunmul.com/index.php/diglosia/article/view/71

\section{PENGARUH STRATEGI PEMBELAJARAN AKTIF TIPE GIVING QUESTION AND GETTING ANSWER TERHADAP HASIL BELAJAR BAHASA INDONESIA SISWA SEKOLAH DASAR}

\author{
The Effect of Active Learning Strategy Type Giving Question and Getting Answer \\ toward Learning Outcomes of Indonesian Language in Primary School Students
}

\author{
Afdal $^{1}$, Hani Subakti ${ }^{2, *}$, Febriyanti Sigalingging ${ }^{3}$ \\ ${ }^{1,2,3}$ Fakultas Keguruan dan Ilmu Pendidikan \\ Universitas Widya Gama Mahakam Samarinda \\ ${ }^{1}$ Pos-el: afdal@uwgm.ac.id \\ 2,*Pos-el Korespondensi: hanisubakti@uwgm.ac.id \\ 3Pos-el: febri09021999@gmail.com
}

\begin{abstract}
This study aims to look at the effect of an active learning strategy type giving questions and getting answers to Indonesian primary school students' learning outcomes. This study uses an experimental research method in which there are treatments for the control class and the experimental class. The final results of the study showed the results of the analysis of the influence of active learning strategies type giving a question and getting an answer to the results of Indonesian language learning of third-grade students at SDN 002 Sungai Pinang, Samarinda City in the affective domain had an average affective assessment in the good predicate. This can be seen from the results of the hypothesis test $t_{\text {bitung }}$ is 1.208 with table is 2.006 so that it can be written $t_{\text {count }}<t_{\text {table }}(1.208<2.006)$, which can be interpreted as $\mathrm{Ha}$ is rejected and $\mathrm{HO}$ is accepted. Based on research results in the cognitive realm have the final test results (post-test), the experimental class obtained an average value of 77.69, the bighest value of 100 and the lowest value of 60 . The final test results (post-test), the control class obtained an average value of 49.64, the highest value is 80, and the lowest value is 20. This can also be seen through the hypothesis test results using the t test (independent sample t test), the tcount $=10.175$ and $t_{\text {table }}=1.67$. Hypothesis test tount $>t_{\text {table }}(10,175>1,67)$. Based on the description, it can be concluded that there is an influence of active learning strategy type giving a question and getting an answer to Indonesian students' learning outcomes in the cognitive realm of class III in SDN 002 Sungai Pinang Samarinda City in 2019/2020. Hence, it shows that the hypothesis is accepted.
\end{abstract}

Keywords: strategy, active learning, learning outcomes, Indonesian

\begin{abstract}
Abstrak: Penelitian ini bertujuan melihat pengaruh strategi pembelajaran aktif tipe giving question and getting answer terhadap hasil belajar bahasa Indonesia siswa sekolah dasar. Penelitian ini menggunakan metode penelitian eksperimen yang di dalamnya terdapat perlakuan untuk kelas kontrol dan kelas eksperimen. Hasil akhir penelitian menunjukkan hasil analisis pengaruh strategi pembelajaran aktif tipe giving question and getting answer terhadap hasil belajar bahasa Indonesia siswa kelas III di SD Negeri 002 Sungai Pinang Kota Samarinda dalam ranah afektif memiliki rata-rata penilaian afektif dalam predikat baik. Hal ini dilihat dari hasil uji hipotesis thitung adalah 1,208 dengan $t_{\text {tabel }}$ adalah 2,006 sehingga dapat ditulis thitung $<\mathrm{t}_{\text {tabel }}(1,208<2,006)$ yang dapat diartikan $\mathrm{Ha}$ ditolak dan $\mathrm{HO}$ diterima. Berdasarkan hasil penelitian dalam ranah kognitif memiliki hasil tes akhir (posttest), kelas eksperimen memperoleh nilai rata-rata 77,69 nilai tertinggi 100 dan nilai terendah 60. Hasil tes akhir (posttest), kelas kontrol memperoleh nilai rata-rata 49,64, nilai tertinggi 80 dan nilai terendah 20. Hal ini dapat dilihat juga melalui hasil uji hipotesis yang menggunakan uji $\mathrm{t}$ (independent sample $t$ test), nilai $\mathrm{t}_{\text {hitung }}=10,175$
\end{abstract}


dan $t_{\text {tabel }}=1,67$. Uji hipotesis $t_{\text {hitung }}>t_{\text {tabel }}(10,175>1,67)$. Berdasarkan uraian dapat disimpulkan bahwa terdapat pengaruh strategi pembelajaran aktif tipe giving question and getting answer terhadap hasil belajar bahasa Indonesia siswa dalam ranah kognitif kelas III di SD Negeri 002 Sungai Pinang Kota Samarinda tahun pembelajaran 2019/2020 sehingga hal tersebut menunjukkan bahwa hipotesis diterima.

Kata kunci: strategi, pembelajaran aktif, hasil belajar, bahasa Indonesia

\section{A. PENDAHULUAN}

Dewasa ini manusia dapat mengembangkan potensi, karakter, dan akhlaknya melalui pendidikan yang berkompeten. Hadirnya kurikulum 2013 diharapkan menciptakan sumber daya manusia berkualitas karena generasi baru inilah yang melanjutkan pembangunan bangsa. Kurikulum 2013 telah didesain berbasiskan karakter yang bukan hanya sekadar di bidang pengetahuan saja tetapi lebih membentuk karakter kepribadian dan akhlak yang baik.

Dalam penerapan kurikulum 2013 banyak strategi pembelajaran yang bervariatif. Strategi pembelajaran yang lama dengan model ceramah kurang membuat minat belajar siswa meningkat. Di sisi lain, semakin tinggi minat belajar, semakin tinggi pula hasil belajar yang diperoleh siswa.

Strategi belajar yang aktif dapat meningkatkan minat belajar siswa dalam proses pembelajaran. Di sisi lain strategi pembelajaran memiliki banyak tipe, satu di antaranya adalah strategi giving question and getting answer. Strategi ini dapat meningkatkan kondisi pembelajaran yang aktif dan memberikan kesempatan siswa untuk dapat mengemukakan pendapatnya. Strategi giving question and getting answer memiliki tipe untuk membangkitkan kondisi kelas yang lebih aktif dan membuat siswa berpikir tentang pembelajaran yang kurang dipahami. Desain strategi pembelajaran aktif dapat membuat suasana kelas lebih menyenangkan serta melibatkan gerak fisik siswa. Strategi pembelajaran aktif juga dapat meningkatkan hasil belajar siswa.

Bahasa Indonesia sebagai salah satu mata pelajaran yang terdapat di kurikulum
2013. Bahasa Indonesia digunakan sebagai sarana untuk mengasah kemampuan berpikir dan mengembangkan diri siswa. Terlebih lagi, di jenjang pendidikan sekolah dasar bahasa Indonesia menjadi tolok ukur peningkatan sumber daya manusia untuk lebih baik (Jamilah, 2019).

Peneliti telah melakukan pengamatan dan mendapatkan informasi mengenai masalah yang ada di kelas III SD Negeri 002 Sungai Pinang, maka penelitian ini berfokus pada hasil belajar bahasa Indonesia siswa. Dipilihnya kelas III di SD Negeri 002 Sungai Pinang karena dari hasil pengamatan terdapat masalah, yaitu rendahnya hasil belajar bahasa Indonesia. Hal tersebut disebabkan pembelajaran yang masih berpusat kepada guru sehingga siswa kurang aktif dalam bertanya.

Penelitian ini bertujuan untuk mengetahui adanya pengaruh strategi pembelajaran aktif tipe giving question and getting answer terhadap hasil belajar bahasa Indonesia siswa di sekolah dasar. Adapun manfaat dari penelitian ini untuk meningkatkan keaktifan siswa dalam proses pembelajaran dan mengenalkan strategi pembelajaran yang membuat siswa aktif. Hingga pada akhirnya, proses pembelajaran bahasa Indonesia dapat terintegrasi dengan baik.

Strategi pembelajaran adalah usaha untuk mengembangkan potensi siswa melalui media pembelajaran dan sumber belajar (Nursalam, 2016). Serupa dengan pendapat sebelumnya Marliana \& Suhertuti (2018) mengemukakan pendapat strategi pembelajaran merupakan proses pembelajaran yang melibatkan guru dan siswa untuk membuat pembelajaran lebih berguna dan sesuai dengan kebutuhan siswa. Pendapat diperkuat oleh Darmadi 
(2018) yang menuliskan bahwa usaha yang dapat dilakukan untuk meningkatkan mutu pendidikan adalah dengan strategi pembelajaran. Berdasarkan uraian tersebut dapat ditarik kesimpulan bahwa strategi pembelajaran adalah usaha yang dilakukan guru untuk mengembangkan kompetensi siswa sehingga dapat meningkatkan mutu pendidikan. Strategi pembelajaran yang tepat meningkatkan minat belajar siswa sehingga siswa dapat mengembangkan kompetensinya. Mutu pendidikan dilihat dari bagaimana hasil belajar siswa dan bagaimana minat belajar sehingga mencapai pembelajaran yang aktif dan menyenangkan.

Strategi pembelajaran aktif tipe giving question and getting answer adalah strategi yang digunakan untuk melatih kemampuan bertanya dan menjawab pertanyaan. Strategi ini membuat pembelajaran yang berlangsung lebih aktif. Strategi ini juga melatih kemampuan bertanya siswa. Strategi pembelajaran aktif tipe giving question and getting answer merupakan strategi yang menarik siswa untuk bertanya, memberikan pendapat dan bekerja kelompok sehingga semua siswa dapat berperan aktif dalam proses pembelajaran (Aprianti \& Edi, 2017). Berdasarkan uraian dapat disimpulkan strategi pembelajaran aktif tipe giving question and getting answer adalah strategi yang digunakan untuk melatih kemampuan bertanya dan menjawab siswa.

Hasil belajar adalah fase akhir dalam proses pembelajaran (Astiti, 2017). Fase akhir dalam proses pembelajaran untuk mengetahui sejauh mana pemahaman siswa. Hasil belajar dapat dilihat dari pengetahuan maupun keterampilan. Serupa dengan pendapat sebelumnya, Syarifudin, dkk (2019) mendefinisikan hasil belajar yang merupakan tolok ukur kemampuan siswa yang diperoleh dari penilaian pada saat proses belajar. Setelah proses pembelajaran dilaksanakan penilaian untuk mengetahui kemampuan siswa. Melalui hasil belajar guru mengetahui sampai sejauh mana kemampuan siswa tersebut menyerap pembelajaran.

Hasil belajar untuk melihat perubahan tingkah laku bagi siswa setelah selesai proses pembelajaran (Matondang et al., 2019). Seorang guru harus memahami bagaimana tingkah laku siswa karena tingkah laku siswa setelah selesai proses pembelajaran adalah cerminan hasil belajar. Berdasarkan uraian di atas dapat disimpulkan pengertian hasil belajar adalah suatu komponen dalam proses pembelajaran yang berada di fase akhir. Hasil belajar juga sebagai bahan evaluasi guru dalam mengajar. Mengetahui kemampuan siswa juga diperoleh dari hasil belajar dan sebagai tolok ukur guru.

Faktor-faktor yang memengaruhi hasil belajar terbagi dua, yaitu faktor dari dalam (internal) dan faktor dari luar (eksternal). Faktor dari dalam diri siswa sangat berpengaruh kepada proses pembelajaran (Parwati et al., 2018) . Faktor dari dalam siswa terbagi menjadi tiga faktor, yaitu (1) faktor jasmani yang memiliki peran mempengaruhi hasil belajar, yaitu pancaindra, (2) faktor kejiwaan yang memengaruhi proses pembelajaran siswa, (3) faktor kelelahan dibagi menjadi dua faktor, yaitu faktor jasmani maupun rohani.

Faktor-faktor dari luar diri siswa juga sangat berpengaruh pada hasil belajar siswa (Parwati et al., 2018). Faktor dari luar dibagi menjadi tiga faktor, yaitu (1) faktor keluarga sebagaimana orang tua mendidik anak, kondisi rumah, kondisi ekonomi keluarga, perhatian orang tua, latar belakang keluarga, dan kebudayaan yang ada dalam keluarga, (2) faktor sekolah sebagaimana cara guru mengajar, metode yang digunakan, kurikulum yang berlaku, komunikasi guru dengan siswa, kedisiplinan, media pembelajaran, waktu, standar pelajaran, kondisi fisik sekolah, dan tugas yang diberikan guru (3) faktor 
masyarakat merupakan kegiatan siswa di tengah-tengah masyarakat dan lingkungan.

Hasil belajar menurut (Susanto, 2016) menjelaskan faktor yang memengaruhi hasil belajar dibagi menjadi dua faktor. Faktor yang memengaruhi hasil belajar, yaitu dari dalam dan luar diri siswa. Faktor dari dalam meliputi kemampuan siswa, kesiapan siswa, bakat, kemauan, dan minat. Faktor dari luar diri siswa meliputi model pembelajaran, suasana belajar, sikap guru, kemampuan guru, keluarga, serta masyarakat. Berdasarkan uraian di atas dapat disimpulkan dua faktor yang memengaruhi hasil belajar. Faktor tersebut adalah dari dalam diri siswa dan dari luar diri siswa. Faktor yang berasal dalam diri siswa adalah jasmani, kemampuan siswa, dan minat belajar siswa. Faktor yang berasal dari luar, yaitu model pembelajaran, keluarga dan masyarakat.

Tujuan pembelajaran bahasa Indonesia pada Kurikulum 2013 untuk mata pelajaran bahasa Indonesia, yaitu peserta didik memiliki kemampuan di bidang kebahasaan khususnya bahasa Indonesia (Arifin, 2019). Adapun rinciannya sebagai berikut: (1) memahami struktur teks, baik dalam genre sastra maupun nonsastra, (2) membandingkan teks dalam bentuk lisan dan tulisan, (3) mengevaluasi teks berdasarkan kaidahkaidah teks, (4) guru lebih mandiri dan leluasa dalam menentukan bahan ajar kebahasaan dan kesastraan sesuai dengan kondisi lingkungan sekolah dan kemampuan peserta didiknya, (5) orang tua dan masyarakat dapat secara aktif terlibat dalam pelaksanaan program kebahasaan, (6) sekolah dapat menyusun program pendidikan tentang kebahasaan dan kesastraan sesuai dengan keadaan peserta didik, dan (7) daerah dapat menentukan bahan dan sumber belajar kebahasaan dan kesastraan sesuai dengan kondisi dan kekhasan daerah. Berdasarkan pendapat tersebut dapat disimpulkan bahwa pembelajaran bahasa Indonesia sangat penting bagi siswa sekolah dasar.
Hal ini dikarenakan pelajaran bahasa Indonesia erat kaitannya dengan kehidupan siswa di dalam masyarakat luas. Pelajaran bahasa Indonesia dapat membentuk karakter siswa sejak dini dalam memahami segala aspek kebahasaan dari hal terkecil hingga hal terbesar. Oleh karena itu, perlu pendampingan dari orang tua, guru, pemerintah daerah, dan pemerintah pusat akan pentingnya bahasa Indonesia khususnya bagi siswa di sekolah dasar.

\section{B. METODE}

Penelitian ini menggunakan metode penelitian eksperimen yang di dalamnya terdapat perlakuan. Metode ini memiliki kelas kontrol dan kelas eksperimen. Metode ini digunakan untuk mengetahui pengaruh perlakuan terhadap kelas eksperimen dan kelas yang dalam kondisi yang terkontrol (Sugiyono, 2018). Desain yang digunakan adalah quasi experimental design. Jenis penelitian ini adalah pengembangan dari jenis penelitian true experimental design. Desain ini memiliki kelas kontrol yang tidak sepenuhnya mengontrol variabel-variabel luar yang memengaruhi pelaksanaan eksperimen.

Penelitian eksperimen adalah bagian dari penelitian kuantitatif yang di dalamnya terdapat kelas kontrol atau kelas yang tidak terapkan perlakuan dan kelas eksperimen yang diterapkan perlakuan (Ismail, 2018). Menurut (Setyosari, 2016) penelitian eksperimen adalah penelitian yang melihat pengaruh kelas yang tidak diterapkan perlakuan dan tidak diterapkan perlakuan. Quasi experimental design merupakan bagian dalam penelitian eksperimen. Desain ini murni dalam dunia pendidikan, subjek dipilih secara acak, peneliti membentuk subjek sesuai dengan rancangannya.

Penelitian ini dilaksanakan di SD Negeri 002 Sungai Pinang, Kecamatan Sungai Pinang, Kota Samarinda. Waktu penelitian dilaksanakan pada semester genap tahun pembelajaran 2019/2020, 
yaitu bulan Maret sampai April 2020. Adapun populasi dari penelitian ini adalah siswa kelas III tahun pembelajaran 2019/2020 SD Negeri 002 Sungai Pinang. Sampel penelitian ini adalah siswa kelas III $C$ yang berjumlah 27 siswa dan kelas III D yang berjumlah 28 siswa tahun pembelajaran 2019/2020 Sungai Pinang. Sampel dipilih dengan teknik sampling dengan menggunakan teknik sampling jenuh. Sampling jenuh adalah jika seluruh anggota populasi dijadikan sebagai sampel. Cara pengambilan kelas kontrol dan kelas eksperimen dengan cara melakukan pretest, hasil nilai rata-rata tertinggi dari setiap kelas yang dijadikan kelas kontrol sedangkan nilai rata-rata terendah menjadi kelas eksperimen.

Uji validitas digunakan untuk menguji keabsahan dalam data penelitian (Sugiyono, 2018). Validitas ketepatan data yang diteliti terhadap objek yang diteliti. Jika data yang dilaporkan tidak sesuai dengan objek maka dinyatakan tidak valid. Data yang dinyatakan valid jika $t_{\text {hitung }}>t_{\text {tabel }}$ dan bernilai positif dan tidak valid jika $\mathrm{t}_{\text {hitung }}<\mathrm{t}_{\text {tabel }}$ dan bernilai negatif. Jika menggunakan koefisien korelasi, maka koefisien korelasi harus sama dengan atau lebih dari 0,3 maka dinyatakan valid. Uji reliabilitas digunakan untuk menguji keabsahan dalam data penelitian (Sugiyono, 2018). Jika objek yang diteliti valid pasti reliabel tetapi jika objek reliabel belum tentu valid.

Penelitian ini menggunakan tes tertulis. Tes yang dilakukan terbagi dua, yaitu tes awal dan akhir. Tes awal (pretest) adalah sebelum diterapkan strategi pembelajaran giving question and getting answer. Tes akhir (posttest) adalah sesudah diterapkan strategi pembelajaran giving question and getting answer. Penelitian ini menggunakan observasi, untuk menilai sikap siswa (penilaian afektif). Observasi penilaian dilakukan pada saat melaksanakan eksperimen sehingga peneliti langsung melihat bagaimana sikap spiritual maupun sikap sosial. Data yang tersimpan akan dibuat ke dalam bentuk dokumentasi. Data yang digunakan berupa foto, daftar peserta didik, dan surat-surat.

Uji normal untuk mengetahui data yang dianalisis berdistribusi normal atau tidak normal. Uji normalitas dapat menggunakan uji Kolmogrov-Sminrnov. Kriteria normalitas, yaitu jika Sig $>\alpha=$ 0,05 dan tidak berdistribusi normal jika Sig. $<\alpha=0,05$. Uji homogenitas dilakukan agar mengetahui variabel $\mathrm{X}$ dan $\mathrm{Y}$ bersifat homogen atau tidak. Uji homogenitas yang dilakukan menggunakan Levene Statistic. Jika nilai signifikan $>0,05$ maka datanya berdistribusi homogen, sedangkan nilai signifikan $<0,05$ maka datanya berdistribusi tidak homogen. Uji hipotesis dapat dicari dengan uji $\mathrm{T}$, uji hipotesis berguna untuk menjawab hasil dari dugaan sementara.

\section{PEMBAHASAN}

Observasi dilakukan pada kelas III di SD Negeri 002 Sungai Pinang kelas III C merupakan kelas eksperimen menggunakan strategi belajar aktif giving question and getting answers berjumlah 26 siswa sedangkan pada kelas III D merupakan kelas kontrol menggunakan strategi pembelajaran ekspositori berjumlah 28 siswa. Observasi dilaksanakan pada saat proses eksperimen di kelas. Hasil observasi dapat dilihat melalui Tabel 1.

Tabel 1 menunjukkan bahwa rata-rata hasil penilaian afektif kelas eksperimen dan kontrol tidak jauh berbeda, hanya selisih 0,08 dengan masing-masing predikat, yaitu baik. Nilai rata-rata dan predikat tersebut yang tidak jauh berbeda, maka dapat ditarik kesimpulan bahwa tidak terdapat pengaruh yang signifikan terhadap penilaian afektif.

Tabel 1. Rata-Rata Penilaian Afektif

\begin{tabular}{lcc}
\hline Keterangan & $\begin{array}{c}\text { Kelas } \\
\text { Eksperimen }\end{array}$ & $\begin{array}{c}\text { Kelas } \\
\text { Kontrol }\end{array}$ \\
\hline Rata-rata & 3,29 & 3,21 \\
Predikat & Baik & Baik \\
\hline
\end{tabular}


Tabel 2. Rekapitulasi Nilai

\begin{tabular}{lcc}
\hline \multicolumn{1}{c}{ Taraf } & $\begin{array}{c}\text { Kelas } \\
\text { Eksperimen }\end{array}$ & $\begin{array}{c}\text { Kelas } \\
\text { Kontrol }\end{array}$ \\
\hline $\begin{array}{l}\text { Nilai tertinggi } \\
\text { (pretest) }\end{array}$ & 80 & 80 \\
$\begin{array}{l}\text { Nilai terendah } \\
\text { (pretest) }\end{array}$ & 10 & 10 \\
$\begin{array}{l}\text { Rata-rata (pretest) } \\
\text { Nilai tertinggi }\end{array}$ & 35,77 & 36,43 \\
(posttest) & 100 & 80 \\
$\begin{array}{l}\text { Nilai terendah } \\
\text { (posttest) }\end{array}$ & 60 & 20 \\
$\begin{array}{l}\text { Rata-rata } \\
\text { (posttest) }\end{array}$ & 77,69 & 49,64 \\
\hline
\end{tabular}

Berdasarkan penelitian yang dilakukan pada kelas III di SD Negeri 002 Sungai Pinang kelas III C merupakan kelas eksperimen menggunakan strategi belajar aktif giving question and getting answers berjumlah 26 siswa, sedangkan pada kelas III D merupakan kelas kontrol menggunakan strategi pembelajaran ekspositori berjumlah 28 siswa. Penelitian menggunakan instrumen soal uraian, sebelum melakukan penelitian terlebih dahulu soal bahasa Indonesia dilakukan uji coba instrumen. Terdapat 10 soal yang valid dan yang digunakan untuk penelitian 10 butir soal.

Hasil rekapitulasi nilai terhadap hasil belajar bahasa Indonesia pada kelas III di SD Negeri 002 Sungai Pinang, kelas eksperimen pada awal tes (pretest) sebelum diberikannya perlakuan memperoleh nilai tertinggi, yaitu 80 dan nilai terendah, yaitu 10, dengan nilai rata-rata, yaitu 35,77. Nilai tes setelah diberikannya perlakuan (posttest) menggunakan strategi belajar aktif giving question and getting answers memperoleh nilai tertinggi, yaitu 100 dan nilai terendah, yaitu 60, dengan nilai rata-rata, yaitu 77,69.

Kelas kontrol yang sejak awal menggunakan strategi pembelajaran ekspositori, pada awal tes (pretest) memperoleh nilai tertinggi, yaitu 80 dan nilai terendah, yaitu 10, dengan nilai ratarata 36,43 lalu hasil tes akhir (posttest) memperoleh nilai tertinggi 80 dan nilai terendah 20 dengan nilai rata-rata 49,64. Berdasarkan uraian si atas dapat disimpulkan kelas eksperimen menggunakan strategi belajar aktif giving question and getting answers yang nilai ratarata lebih tinggi daripada kelas kontrol yang menggunakan strategi pembelajaran ekspositori.

\section{Uji Validitas}

Berdasarkan hasil analisa data uji coba instrumen yang telah dilakukan. Perhitungan validitas data menggunakan rumus product moment melalui aplikeasi IBM SPSS 23. Penelitian hasil belajar bahasa Indonesia pada uji coba instrumen dengan soal uraian berjumlah 10 butir soal yang diperoleh 10 butir soal valid, artinya dari 10 butir item semuanya dinyatakan valid.

Tabel 3. Validitas Instrumen Tes

\begin{tabular}{cccc}
\hline Butir Tes & $\mathbf{r}_{\text {hitung }}$ & $\mathbf{r}_{\text {tabel }}$ & Status \\
\hline 1 & 0,374 & 0,758 & Valid \\
2 & 0,374 & 0,679 & Valid \\
3 & 0,374 & 0,732 & Valid \\
4 & 0,374 & 0,687 & Valid \\
5 & 0,374 & 0,502 & Valid \\
6 & 0,374 & 0,731 & Valid \\
7 & 0,374 & 0,511 & Valid \\
8 & 0,374 & 0,621 & Valid \\
9 & 0,374 & 0,621 & Valid \\
10 & 0,374 & 0,814 & Valid \\
\hline
\end{tabular}

\section{Uji Reabilitas}

Uji reliabilitas dilakukan dengan tujuan melihat konsistensi tes kapan pun disajikan. Uji reliabilitas pada penelitian ini menggunakan perhitungan SPSS dengan teknik analisis Cronbach's Alpha. Instrumen tes yang dinyatakan reliabel jika nilai cronbach alpha $>0,7$. Berdasarkan nilai reliabilitas pada angket keterlibatan orang tua diperoleh nilai $\mathrm{r}=0,855$. Setelah dibandingkan dengan nilai Cronbach's Alpha, yaitu 0,7 maka hasil dari uji reliabilitas dinyatakan reliabel dan instrumen tes dapat digunakan. 


\section{Uji Normalitas}

Uji normalitas diperoleh dari hasil pengolahan data melalui IBM SPSS 23 dengan kriteria normalitas, yaitu jika Sig $>$ $\alpha=0,05$ dan tidak berdistribusi normal jika Sig $<\alpha=0,05$.

Tabel 4. Uji Normalitas

\begin{tabular}{lcc}
\hline \multicolumn{1}{c}{ Jenis Kelas } & Sig & Ket. \\
\hline $\begin{array}{l}\text { Kelas Eksperimen } \\
\text { (Afektif) }\end{array}$ & 0,110 & Normal \\
$\begin{array}{l}\text { Kelas Kontrol (Afektif) } \\
\begin{array}{l}\text { Kelas Eksperimen } \\
\text { (Kognitif) }\end{array}\end{array}$ & 0,120 & \\
Kelas Kontrol (Kognitif) & 0,138 & Normal \\
\hline
\end{tabular}

\section{Uji Homogenitas}

Uji afektif ranah afektif yang dilakukan menggunakan levene statistic dengan menggunakan IBM SPSS 23. Jika nilai signifikan $>0,05$ maka datanya berdistribusi homogen, sedangkan nilai signifikan $<0,05$ maka datanya berdistribusi tidak homogen. Hasil dari uji homogenitas menggunakan levene statistic adalah 0,209 > 0,05, jadi dapat disimpulkan bahwa data tersebut dinyatakan homogen.

Uji homogenitas ranah kognitif yang dilakukan menggunakan levene statistic dengan menggunakan IBM SPSS 23. Jika nilai signifikan $>0,05$ maka datanya berdistribusi homogen, sedangkan nilai signifikan $<0,05$ maka datanya berdistribusi tidak homogen. Hasil dari uji homogenitas menggunakan levene statistic adalah 0,68>0,05, jadi dapat disimpulkan bahwa data tersebut dinyatakan homogen.

\section{Uji Hipotesis}

Uji hipotesis dapat dicari dengan uji $\mathrm{T}$, uji hipotesis berguna untuk menjawab hasil dari dugaan sementara. Setelah melakukan uji normalitas dan uji homogenitas, selanjutnya akan dilakukan analisis data untuk menguji hipotesis.

Dari Tabel 5 dapat dilihat bahwa perhitungan uji hipotesis yang dilakukan di kelas eksperimen dan di kelas kontrol, maka didapatkan $t_{\text {hitung }}$ adalah 1,208 dengan $t_{\text {tabel }}$ adalah 2,006 sehingga dapat ditulis $t_{\text {hitung }}<\mathrm{t}_{\text {tabel }}(1,208<2,006)$ yang dapat diartikan $\mathrm{Ha}$ ditolak dan $\mathrm{HO}$ diterima. Berdasarkan perhitungan, dapat disimpulkan nilai afektif kelas eksperimen yang menggunakan strategi pembelajaran aktif getting question and giving answer hampir sama dengan nilai afektif kelas kontrol yang menggunakan strategi pembelajaran ekspositori.

Tabel 5. Uji Hipotesis

\begin{tabular}{|c|c|c|c|}
\hline Kelas & $\mathbf{t}_{\text {hitung }}$ & $t_{\text {tabel }}$ & Keputusan \\
\hline Kelas & & & \\
\hline $\begin{array}{l}\text { Eksperimen } \\
\text { dan Kelas } \\
\text { Kontrol } \\
\text { Afektif } \\
\text { Kelas }\end{array}$ & 1,208 & 2,006 & $\begin{array}{c}\text { thitung }<\mathrm{t}_{\text {tabel }} \\
{\text { maka } \mathrm{H}_{\mathrm{a}}}_{\text {ditolak }}\end{array}$ \\
\hline $\begin{array}{l}\text { Eksperimen } \\
\text { dan } \\
\text { Kelas } \\
\text { Kontrol } \\
\text { Kognitif }\end{array}$ & 10,15 & 1,67 & $\begin{array}{l}\mathrm{t}_{\text {hitung }}<\mathrm{t}_{\text {tabel }} \\
\text { maka } \mathrm{H}_{\mathrm{a}} \\
\text { diterima }\end{array}$ \\
\hline
\end{tabular}

Berpedoman dari Tabel 5, perhitungan uji hipotesis dilakukan di kelas eksperimen dan di kelas kontrol, didapatkan $t_{\text {hitung }} 10,175$ dengan $t_{\text {tabel }} 1,67$ sehingga dapat ditulis thitung $>t_{\text {tabel }}(10,175$ $>1,67)$ yang dapat diartikan $H a$ diterima dan $H O$ ditolak. Berdasarkan perhitungan, dapat disimpulkan nilai kognitif kelas eksperimen yang menggunakan strategi pembelajaran aktif getting question and giving answer lebih tinggi daripada nilai kognitif kelas kontrol yang menggunakan strategi pembelajaran ekspositori.

\section{Pembahasan}

Hasil observasi dapat dilihat bahwa nilai rata-rata dan predikat yang tidak jauh berbeda. Hasil tersebut menunjukkan bahwa tidak terdapat pengaruh signifikan strategi pembelajaran aktif tipe giving question and getting answer terhadap penilaian afektif siswa kelas III di SD Negeri 002 Sungai Pinang. Hal ini disebabkan karena penilaian afektif tidak menjadi masalah utama dalam penelitian ini. Strategi- 
strategi pembelajaran tidak terlepas dari penanaman karakter sehingga sikap siswa rata-rata dalam predikat baik.

Bertolok dari perhitungan uji hipotesis yang dilakukan di kelas eksperimen dan di kelas kontrol, maka didapatkan $t_{\text {hitung }}$ 1,208 dengan $t_{\text {tabel }}$ 2,006 sehingga dapat ditulis $t_{\text {hitung }}<\mathrm{t}_{\text {tabel }}(1,208<$ $2,006)$ yang dapat diartikan $\mathrm{Ha}$ ditolak dan HO diterima. Berdasarkan perhitungan tersebut, dapat disimpulkan nilai afektif kelas eksperimen yang menggunakan strategi pembelajaran aktif getting question and giving answer hampir sama dengan nilai afektif kelas kontrol yang menggunakan strategi pembelajaran ekspositori. Hasil uji hipotesis yang diperoleh tidak terdapat pengaruh signifikan strategi pembelajaran aktif tipe giving question and getting answer terhadap penilaian afektif siswa kelas III di SD Negeri 002 Sungai Pinang.

Pemahaman konsep dalam ranah pengetahuan terdapat perbedaan yang signifikan antara strategi pembelajaran yang digunakan kelas eksperimen dan kelas kontrol. Strategi pembelajaran yang digunakan kelas eksperimen adalah strategi pembelajaran aktif tipe giving question and getting answer, yaitu strategi yang berpusat kepada siswa. Siswa lebih aktif dalam pembelajaran, sedangkan tugas guru hanya sebagai fasilitator bagi siswa. Berbanding terbalik dengan strategi yang digunakan kelas kontrol, yaitu strategi pembelajaran ekspositori. Strategi pembelajaran ekspositori atau yang lebih dikenal dengan metode ceramah, strategi ini berpusat kepada guru sehingga siswa bersikap pasif.

Hasil tes akhir (posttest), kelas eksperimen memperoleh nilai rata-rata 77,69, nilai tertinggi 100 dan nilai terendah 60. Hasil tes akhir (posttest), kelas kontrol memperoleh nilai rata-rata 49,64, nilai tertinggi 80 dan nilai terendah 20. Melalui penjelasan tersebut dapat disimpulkan nilai rata-rata tersebut kelas eksperimen memiliki nilai rata-rata yang lebih tinggi dari nilai rata-rata kelas kontrol.
Hasil uji hipotesis yang menggunakan uji $\mathrm{t}$ (independent sample $t$ test), nilai $\mathrm{t}_{\text {hitung }}=$ 10,175 dan $\mathrm{t}_{\text {tabel }}=1,67$. Uji hipotesis thitung $>t_{\text {tabel }}(10,175>1,67)$, maka dapat disimpulkan bahwa hipotesis diterima. Hasil uji hipotesis yang diperoleh terdapat pengaruh signifikan strategi pembelajaran aktif tipe giving question and getting answer terhadap penilaian kognitif siswa kelas III di SD Negeri 002 Sungai Pinang.

Melalui hasil belajar ranah afektif tidak terdapat perbedaan yang signifikan melalui rata-rata predikat siswa sedangkan dalam ranah kognitif terdapat perbedaan rata-rata kelas eksperimen dan kelas kontrol. Hasil uji hipotesis juga menyatakan bahwa pada ranah afektif hipotesis ditolak, maka terdapat pengaruh signifikan, sedangkan hasil uji hipotesis juga menyatakan bahwa pada ranah kognitif hipotesis diterima, maka terdapat pengaruh signifikan. Hal tersebut dikarenakan semua strategi pembelajaran menerapkan penanaman karakter pada setiap pembelajaran sedangkan dalam ranah kognitif strategi tersebut bertolak belakang. Berdasarkan penjelasan tersebut dan penelitian terdahulu yang relevan dengan penelitian ini, hal ini berarti diterimanya hipotesis, yaitu terdapat pengaruh signifikan penerapan strategi giving questions and getting answer terhadap hasil belajar siswa dalam ranah kognitif.

\section{PENUTUP}

Hasil observasi dapat dilihat bahwa nilai rata-rata dan predikat yang tidak jauh berbeda. Hasil tersebut menunjukkan bahwa tidak terdapat pengaruh signifikan strategi pembelajaran aktif tipe giving question and getting answer terhadap hasil belajar bahasa Indonesia pada penilaian afektif siswa kelas III di SD Negeri 002 Sungai Pinang Kota Samarinda. Hal ini disebabkan karena strategi-strategi pembelajaran tidak terlepas dari penanaman karakter sehingga sikap siswa rata-rata dalam predikat baik. 
Hasil penelitian mengenai pengaruh strategi pembelajaran aktif tipe giving question and getting answer terhadap hasil belajar bahasa Indonesia siswa kelas III di SD Negeri 002 Sungai Pinang Kota Samarinda dalam ranah afektif memiliki rata-rata penilaian afektif dalam predikat baik. Hal ini dilihat juga dari hasil uji hipotesis $t_{\text {hitung }}$ adalah 1,208 dengan $t_{\text {tabel }}$ adalah 2,006 sehingga dapat ditulis $t_{\text {hitung }}<$ $t_{\text {tabel }}(1,208<2,006)$ yang dapat diartikan $\mathrm{Ha}$ ditolak dan $\mathrm{HO}$ diterima. Berdasarkan uraian tersebut dapat disimpulkan bahwa tidak terdapat pengaruh strategi pembelajaran aktif tipe giving question and getting answer terhadap hasil belajar bahasa Indonesia siswa dalam ranah afektif kelas III di SD Negeri 002 Sungai Pinang Kota Samarinda tahun pembelajaran 2019/2020 sehingga hal tersebut menunjukkan bahwa hipotesis ditolak.

Hasil analisis mengenai pengaruh strategi pembelajaran aktif tipe giving question and getting answer terhadap hasil belajar bahasa Indonesia siswa kelas III di SD Negeri 002 Sungai Pinang Kota Samarinda dalam ranah kognitif kelas III di SD Negeri 002 Sungai Pinang Kota Samarinda tahun pembelajaran 2019/2020 memiliki hasil tes akhir (posttest), kelas eksperimen memperoleh nilai rata-rata 77,69, nilai tertinggi 100 dan nilai terendah 60. Hasil tes akhir (posttest), kelas kontrol memperoleh nilai rata-rata 49,64, nilai tertinggi 80 dan nilai terendah 20. Hal ini dapat dilihat melalui hasil uji hipotesis yang menggunakan uji $\mathrm{t}$ (independent sample t test), nilai $\mathrm{t}_{\text {hitung }}=10,175$ dan $\mathrm{t}_{\text {tabel }}=1,67$. Uji hipotesis $t_{\text {hitung }}>t_{\text {tabel }}(10,175>1,67)$. Berdasarkan uraian tersebut dapat disimpulkan bahwa terdapat pengaruh strategi pembelajaran aktif tipe giving question and getting answer terhadap hasil belajar bahasa Indonesia siswa dalam ranah kognitif kelas III di SD Negeri 002 Sungai Pinang tahun pembelajaran $2019 / 2020$ sehingga hal tersebut menunjukkan bahwa hipotesis diterima.

\section{DAFTAR PUSTAKA}

Aprianti, F., \& Edi, R. (2017). Pengaruh Strategi Pembelajaran Aktif Tipe Giving Question and Getting Answer terhadap Hasil Belajar Kimia SMAN 1 Indralaya. 214-226. Diakses melalui http:// conference.unsri.ac.id/index. $\mathrm{php} /$ semnasipa/article/download/6 90/307

Arifin, S., Yahya, M., \& Siddik, M. (2019). Strategi Komunikasi Siswa dan Guru Kelas XI SMAN 2 Sangatta Utara dalam Proses Pembelajaran Bahasa Indonesia. Diglosia: Jurnal Kajian Sastra, Bahasa, dan Pengajarannya, 2(1), 15-38.

http://diglosiaunmul.com/index.ph $\mathrm{p} /$ diglosia/article/view/3

Arifin, Z. 2016. Evaluasi Pembelajaran (Prinsip, Teknik, dan Prosedur), Cetakan Kedelapan, Jakarta: Rosda Karya.

Astiti, K. A. (2017). Evaluasi Pembelajaran. Yogyakarta: Andi Offset.

Ayu, I. G., Indrayani, K., \& Sumantri, M. (2018). Pengaruh Strategi Pembelajaran Giving Question and Getting Answer ( GQGA ) terbadap Hasil Belajar Matematika. 112-119. Diakses melalui https://ejournal.undiksha.ac.id/inde x.php/JJPGSD/article/download/1 9465/11528

Darmadi, H. (2018). Optimalisasi Strategi Pembelajaran: Inovasi Tiada Henti Meningkatkan Kualitas Proses dan Hasil Belajar Peserta Didik. Bogor: Guepedia Publisher.

Devi, Y. (2019). Pengaruh Strategi Pembelajaran Aktif Tipe Giving Question and Getting Answer (GQGA) Terhadap Hasil Belajar Matematika Siswa Kelas $V$ SD Negeri 106805 Desa Manunggal Kecamatan Labuban Deli Kab. Deli Serdang. Diakses melalui http://repository.uinsu.ac.id/id/epri $\mathrm{nt} / 6133$

Ismail, F. (2018). Statistika Untuk Penelitian Pendidikan dan Ilmu-ilmu Sosial. Jakarta: Prenadamedia Group. 
Jamilah, N., Mulawarman, W. G., \& Hudiyono, Y. (2020). Pengembangan Bahan Ajar Interaktif 'POST' dalam Pembelajaran Apresiasi Puisi untuk Siswa Kelas X SMA. Diglosia: Jurnal Kajian Bahasa, Sastra, dan Pengajarannya, 3(1), 14-23. https://doi.org/10.30872/diglosia.v $3 i 1.28$

Kristanto, V. H. (2018). Metodologi Penelitian Pedoman Penulisan Karya Tulis Ilmiah (KTI). Yogyakarta:Deepublish.

Marliana, N. L., \& Suhertuti. (2018). Strategi Belajar Mengajar Bahasa Indonesia. Bandung:Remaja Rodaskarya.

Matondang, Z., Ely, D., Sriadhi, \& Janner, S. (2019). Evaluasi Hasil Belajar. Medan: Yayasan Kita Menulis.

Nursalam, H. (2016). Strategi Belajar Mengajar IPS. Surabaya:Garuda Mas
Sejahtera.

Parwati, N. N., Suryawan, I. P. P., \& Apsari, R. A. (2018). Belajar dan Pembelajaran. Depok: Grafindo Persada.

Setyosari, P. (2016). Metode Penelitian Pendidikan dan Pengembangan. Jakarta:Prenadamedia Group.

Sugiyono. (2018). Metode Penelitian Pendidikan Pendekatan Kualitatif, Kuantitatif, dan R\&D. Bandung: Alfabeta.

Susanto, A. (2016). Teori Belajar dan Pembelajaran di Sekolah Dasar. Jakarta:Prenadamedia.

Syarifudin, Supiono, \& Burhanuddin. (2019). Guru, Mari Kita Menulis Penelitian Tindakan Kelas. Yogyakarta: Deepublish. 